\title{
Modified hybrid genetic algorithm of discreet optimization problems
}

Publisher: IEEE

\author{
A. O. Glukhov; D. O. Glukhov; V. V. Trofimov; L. A. \\ Trofimova
}

\section{Abstract:}

The goal objective is to improve the efficiency of solving discrete optimization problems. The proposed method refers to the "fast" methods and was named the "Local genetic method". The peculiarity of this method is that the chromosomes do not encode the whole solution, but only a small part of the plan. Therefore, the method allows us introducing unary and binary operations that take into account the specific nature of the problem. The important feature of the method is the non-deterministic nature of the computation, which is due to the internal parallelism of computations and is expressed in the asynchronous action of various local strategies. In terms of speed, the proposed method in a number of experiments outperformed the traditional algorithm by more than 10 times and always found the best solution. The nature of the approximation to the optimum for these algorithms remained unchanged when solving any test cases.

Published in: 2017 XX IEEE International Conference on Soft Computing and Measurements (SCM)

Date of Conference: 24-26 May 2017

Date Added to IEEE Xplore: 07 July 2017

ISBN Information:

Electronic ISBN:978-1-5386-1810-3

Print on Demand(PoD) ISBN:978-1-5386-1811-0

INSPEC Accession Number: 17014399

DOI: 10.1109/SCM.2017.7970603

Publisher: IEEE 


\section{Conference Location: St. Petersburg, Russia}

Authors

A. O. Glukhov

Polotsk State University, PSU, Polotsk, Belarus

D. O. Glukhov

Polotsk State University, PSU, Polotsk, Belarus

V. V. Trofimov

St. Petersburg State Economics University, St. Petersburg, Russia L. A. Trofimova

St. Petersburg State Economics University, St. Petersburg, Russia

\section{References}

1.A.O. Gluhov, V.V. Trofimov and L.A. Trofimova, "Approksimaciya slozhnyh mnogoparametricheskih sushchestvenno nelinejnyh dinamicheskih zavisimostej na osnove geneticheskih algoritmov [Approximation of complex multivariable highly nonlinear dynamic dependencies based on genetic algorithms", XIX international conference on soft computing and measurements (SCM-2016), vol. 1, pp. 477-480, 2527 may 2016.

Show in Context Google Scholar

2.A.O. Gluhov and V.V. Trofimov, "Ispol'zovanie rekursivnyh ehvristik pri reshenii zadach diskretnoj optimizacii bol'shoj razmernosti [he use of recursive heuristics in solving problems of discrete optimization of large dimension" in Modern problems of management interuniversity collection, SPb:Izd-vo SpbGUEF, no. 6, pp. 99-105, 2003.

Google Scholar

3.A.O. Gluhov, V.V. Trofimov and D.O. Gluhov, "Lokal'nyj geneticheskij algoritm planirovaniya processa mnogoprofil'nogo proizvodstva [A local genetic algorithm for the planning of the multidisciplinary production" in Economic Cybernetics. Systems analysis in Economics and management. Sat. scientific papers, SPb:SpbGUEF, no. 5, pp. 50-56, 2002. Google Scholar

4.V.V. Trofimov and A.O. Hluhov The, "Optimal Schedule for the Technological Process of Semiconductor Production. Operations Research 2002", International Conference on Operations Research, pp. 148, Sept.2sept.5, 2002.

Show in Context Google Scholar 5.V.V. Trofimov and A.O. Gluhov Metod, "resheniya zadachi identifikacii i modelirovaniya samoorganizuyushchihsya sistem na osnove geneticheskogo podhoda [Method of solving the problem of identification and modeling of self-organizing systems based on genetic 
approach", International conference on soft computing and measurements, vol. 1, pp. 291-293, June 25-27, 2001.

Show in Context Google Scholar

6.V. V. Trofimov and A.O. Hluhov, "Multimedia - The Challenge for Science Technology and Business" in Construction of the Optimal Schedule for the Technological process of semiconducting production. 46. International Scientific Colloquium, Germany:Technique University of IImenau, 092001. Google Scholar

Keywords

- IEEE Keywords

- Genetic algorithms,

- Biological cells,

- Approximation algorithms,

- Optimization,

- Genetics,

- Heuristic algorithms,

- Sociology

- INSPEC: Controlled Indexing

- genetic algorithms

- INSPEC: Non-Controlled Indexing

- modified hybrid genetic algorithm,

- discreet optimization problems,

- local genetic method,

- asynchronous action

- Author Keywords

- genetic algorithms,

- discrete optimization 